\title{
France à fric: the CFA zone in Africa and neocolonialism
}

\author{
Ian Taylor
}

\begin{tabular}{|l|l|}
\hline Date of deposit & 18042019 \\
\hline Document version & Author's accepted manuscript \\
\hline Access rights & $\begin{array}{l}\text { Copyright @ Global South Ltd. This work is made available online } \\
\text { in accordance with the publisher's policies. This is the author } \\
\text { created, accepted version manuscript following peer review and } \\
\text { may differ slightly from the final published version. }\end{array}$ \\
\hline $\begin{array}{l}\text { Citation for } \\
\text { published version }\end{array}$ & $\begin{array}{l}\text { Taylor, I. C. (2019). France à fric: the CFA Zone in Africa and } \\
\text { neocolonialism. Third World Quarterly, Latest Articles. }\end{array}$ \\
\hline $\begin{array}{l}\text { Link to published } \\
\text { version }\end{array}$ & https://doi.org/10.1080/01436597.2019.1585183 \\
\hline
\end{tabular}

Full metadata for this item is available in St Andrews Research

Repository at: https://research-repository.st-andrews.ac.uk/

\section{St Andrews Research Repository}




\section{FRANCE À FRIC: THE CFA ZONE IN AFRICA AND NEOCOLONIALISM}

Over fifty years after 1960 's "Year of Africa," most of Francophone Africa continues to be embedded in a set of associations that fit very well with Kwame Nkrumah's description of neocolonialism, where postcolonial states are de jure independent but in reality constrained through their economic systems so that policy is directed from outside. This article scrutinizes the functioning of the CFA, considering the role the currency has in persistent underdevelopment in most of Francophone Africa. In doing so, the article identifies the CFA as the most blatant example of functioning neocolonialism in Africa today and a critical device that promotes dependency in large parts of the continent. Mainstream analyses of the technical aspects of the CFA have generally focused on the exchange rate and other related matters. However, while important, the real importance of the CFA franc should not be seen as purely economic, but also political.

On the $20^{\text {th }}$ January, 2019, the Italian deputy prime minister, Luigi di Maio, called on the European Union to impose sanctions on France for its policies in Africa. Di Maio went on to say that without Africa, France would rank 15th among world economies, not in the top six and he linked this situation specifically to the CFA currency, asserting that "France is one of those countries that by printing money for 14 African states prevents their economic development". ${ }^{1}$ While Di Maio's intervention arguably had more to do with tensions between the Italian and French governments, particularly over irregular migration from Africa, than a genuine critique of the currency, they did in fact feed into widespread and growing discontent within the continent and generated considerable discussion within and outside Africa vis-à-vis the CFA. ${ }^{2}$ As BNP Paribas, France's largest banking group, noted with some degree of understatement, 'The CFA franc no longer enjoys unanimous support' ${ }^{3}$

Indeed, prior to Di Maio's comments, at the end of August 2017, a Senegalese court acquitted a Franco-Beninese activist who had been charged over burning a 5,000 CFA note in a protest against the currency. It was reported that 'for most of the young people who attended the protest, his act was a legitimate sign of defiance against a currency they consider as a symbol of the economic and financial domination by France of the countries sharing it'. ${ }^{4}$ Less than a year later, in June 2018, ten musicians from seven African countries released a song entitled 7 minutes contre le CFA to mobilise 
opposition to the common currency. ${ }^{5}$ Nearly forty years before these events, Tamar Golan asked how France could do everything that it does in Africa - and get away with it, including the currency arrangements that linked Paris to many of its former colonies. ${ }^{6}$ As Di Maio's statement, the protest in Senegal and the music record attests, the answer to this question perhaps remains unanswered.

This article aims to present a critical analysis of the CFA zone, aiming to demonstrate how the CFA currency is a politico-economic tool of French neocolonial policy in Africa, maintained with the active connivance of Francophone elites on the continent. ${ }^{7}$ The article proceeds by sketching out the colonial origins of the CFA zone before moving on to scrutinize the functioning of the CFA. The way in which France holds an effective veto power on monetary decisions is elucidated, as well as the workings of the Operations Account and how capital generated by African economies is used to the benefit of French interests. How the CFA deepens underdevelopment and dependency within its areas is also discussed. The fact that the CFA as a currency union defies economic commonsense is deliberated, pointing to the central point that the CFA zone is, first and foremost, a political entity. While defenders of the CFA usually refer to the supposed stability of the currency, the credibility provided by the French Treasury and a relatively low inflation rate, the article concludes that the CFA is arguably the most blatant example of functioning neocolonialism in Africa today and a critical device that helps deepen dependency and underdevelopment in large parts of the continent.

\section{La Françafrique}

Of all the former colonial powers in Africa, France has retained the most intense political, social, economic and culturally intense ties after independence, early on recognized as being neocolonial in nature. ${ }^{8}$ Captured in the terms le village franco-africain ${ }^{9}$ or la Françafrique, ${ }^{10}$ highly personalized networks underpin relations, which guarantee access to natural resources and markets in Africa for French interests. ${ }^{11}$ For French economic concerns, Africa is important, given that nuclear power accounts for $80 \%$ of French electricity production ${ }^{12}$ and uranium, sourced from Niger, is crucial. In addition, French industries depend specifically on CFA countries for imports of manganese, chromium and phosphates, minerals all essential for French aeronautics and weaponry production. 
For French corporations active in Africa, the fixed parity of the CFA franc, which is overvalued, means that these French interests are effectively protected from common currency deprecations, while the convertibility and free transfer principles facilitate their repatriation of profits out of the continent. ${ }^{13}$ Due to the overvalued nature of the currency (see below), French commercial interests are able to export and sell their products to the CFA at lower cost.

Equally, France's chasse gardée or domaine reserve on the continent grants Paris an international credibility it would not otherwise possess. ${ }^{14}$ As Kako Nubukpo, professor of Economics at the Université de Lomé, Togo, notes, while African countries give up their monetary sovereignty,

En contrepartie, à travers ce "paternalisme monétaire", la France gagnerait en prestige, une illustration à la face du monde du maintien de l'empire, un pré carré au sein duquel son influence et son rayonnement resteraient entiers, à l'heure où la concurrence des pays émergents (Chine, Inde, Russie, Brésil) se fait plus vive que jamais. ${ }^{15}$

This last point is perhaps now the most important factor in explaining Paris' connections to the continent. ${ }^{16}$

Over fifty years after 1960's "Year of Africa," most of Francophone Africa continues to be embedded in a set of associations that fit well with Kwame Nkrumah's description of neocolonialism, whereby 'the State which is subject to it is, in theory, independent and has all the outward trappings of international sovereignty. In reality its economic system and thus its political policy is directed from outside'. ${ }^{17}$ On the basis of this description, neocolonialism is a system of domination and exploitation, invested and maintained by the former colonial power in which economic, financial and military instruments work for keeping in power well-disposed leaders and maintaining favourable policies which procure economic and financial advantages. ${ }^{18}$ The saliency of neocolonialism remains a powerful as an analytical category to understand contemporary Africa's political economy. ${ }^{19}$

The result of such arrangements in much of Francophone Africa has been continued underdevelopment, understood here as the increasing loss by a society over 
control of its own future; the emergence of structures of external dependency in the economy; net transfers of resources and national wealth to foreigners; a growing gap between the dominated and dominant nations vis-à-vis technology, life chances and living standards and the consolidation of a domestic social structure whereby local elites benefit while the majority do not. ${ }^{20}$ The role of the African elites within the CFA zone in perpetuating this scenario, which is objectively against the interest of their own countries, cannot be underestimated. ${ }^{21}$

From the time of independence onwards, Paris' dominant presence in its former African empire has been based on three pillars. These are, namely, a network of French experts present at the state level of African countries, in financial, institutional, and educational structures. Secondly, the presence of French troops stationed in various military bases across the continent, as well as numerous French military advisers attached to African armies in senior advisory roles. ${ }^{22}$ Finally, a monetary pillar through the Communautés Financières d'Afrique Franc (CFA), made up of two CFA currencies. ${ }^{23}$ CFA is the common name for the two currencies circulating in the fourteen member countries of the zone, which is made up two economic communities. ${ }^{24}$ These are the Communauté Économique des États de l'Afrique Centrale (CEEAC) ${ }^{25}$ and the Union économique et monétaire ouest-africaine (UEMOA), both printed by the Banque de France in Chamalières in Auvergne-Rhône-Alpes. ${ }^{26}$ The outer convertibility of the CFA in both communities is guaranteed by the French Treasury (Trésor public).

The first two pillars of Franco-African policy have been covered in depth. ${ }^{27}$ The third pillar, specifically CFA's role in perpetuating underdevelopment and dependency has increasingly come under spotlight. Recent monographs on the subject have also reignited debate within Africa. ${ }^{28}$ This article seeks to add to the discussion.

\section{Origins of the $\mathrm{CFA}$}

During the 1930s and 1940s, France established in each of its colonies currencies that were pegged to the French franc. ${ }^{29}$ During the Second World War, those African territories under the control of the Free French (so-called Afrique Française Libre) issued banknotes, backed by the Caisse Centrale de la France Libre, an institute sanctioned to circulate currency (this institution moved to Algiers in 1943). ${ }^{30}$ After the war, overseas 
French currencies were consolidated into the Franc des Colonies Françaises d'Afrique (FCFA) and the Franc des Colonies Françaises du Pacifique. ${ }^{31}$ The motivation for this was that when Paris ratified the Bretton Woods Agreement in late 1945, the French franc was devalued so as to put a fixed exchange rate with the American dollar in place. Thus new currencies were established in French territories overseas to both protect them from the devaluation and, crucially, to facilitate exports to France to help Paris rebuild the country after the war, ${ }^{32}$ with Paris using the institutional arrangements to maintain their "right" to African natural resources. ${ }^{33}$

The very genesis of the CFA is colonial and even the division into two different CFAs tracks French imperial division of the continent. ${ }^{34}$ In 1959 the Banque Centrale des Etats de l'Afrique de l'Ouest (BCEAO) was created and began issuing CFA Francs. ${ }^{35} \mathrm{~A}$ similar institution was established in Central Africa, the Banque Centrale des Etats de l'Afrique Equatoriale et du Cameroun (BCEAEC). Both of these were instituted on the eve of independence for most of France's African colonies and thus 'French West Africa and French Equatorial Africa disappeared, but France sought to maintain privileged and lasting political, cultural, economic, and military relations with the former colonies' ${ }^{36}$

The CFA franc zone operates under a number of basic operating norms: (i) a fixed parity against the euro, adjustable if needed, but only after consultation with Paris and the unanimous decision of all members within each monetary area; (ii) convertibility of the CFA franc into the euro; (iii) the guaranteeing of such convertibility by France through each regional central bank holding an operating account with the French Treasury in Paris; (iv) free capital mobility between the two CFA zones and France; and (v) the sharing of foreign exchange reserves of each regional monetary area. ${ }^{37}$

The CFA franc was issued initially by the central bank for France's overseas territories (Caisse Centrale de la France d'outre mer) before being moved, after the independence of most of its former African colonies, to two regional central banks. These banks, completely dominated by France until the early 1970s, eventually secured responsibility for issuing currency. The two different CFA currencies are legal tenders in their particular regional zones only. However, because of their convertibility into the euro, the free capital mobility between each CFA zone and Paris, and that the two CFA 
francs have an identical parity vis-à-vis the euro, the CFA franc zone has conventionally been regarded as one currency sphere with a single currency.

Two agreements drafted in 1972-1973, following the devaluation of the French franc in 1969 by $12.5 \%$, were signed. ${ }^{38}$ Cooperation Convention Articles 5 and 12 saw the French Treasury guarantee unlimited convertibility of the CFA franc at a fixed exchange rate with the French franc. ${ }^{39}$ A lack of de jure controls regarding capital flows within the zone facilitated this. In turn, the headquarters of the two CFA region's respective central banks (BCEAO and BCEAEC) were symbolically moved from Paris to Dakar, Senegal and Yaoundé, Cameroon respectively. However, as one commentator noted at the time, 'The CFA franc continues to be guaranteed by the French Treasury. Thus, for these West African States of French colonial legacy, BCEAO and CFA currency make their economies very dependent on France'. ${ }^{40}$ The main goal of the CFA arrangement was to construct a post-colonial architecture to establish continued French influence and protect Paris' economic interests in terms of access to natural materials, as well as safeguard markets for French manufactured goods. ${ }^{41}$ The net result has been that the CFA franc has helped entrench its member countries' dependent positions as relatively low-priced sources of raw materials. This has been primarily because the two CFA currencies were (and continue to be) set at an unreasonably high level, which limited the price competitiveness of exports onto global world markets (except when these exports went to the French market). Thus, 'the parity was engineered in such a way as to make France's market the exclusive outlet for her former colonies' raw materials: cocoa, coffee, cotton, rubber, uranium, among others' ${ }^{42}$ Continued underdevelopment and dependency has been the net result.

\section{France decides: the value of the CFA}

As noted, the CFA franc was officially born on December 26, 1945 with a parity of 1

FCFA $=1.70$ French francs. ${ }^{43}$ Its parity was later set (October 1948) at 0.5 CFA franc per French franc. This was because between 1945 and 1948, the CFA franc had tracked the devaluation of the French franc against the dollar. However, on 18 October 1948, the French franc was devalued further against the dollar as part of the Bretton Woods process and in response, the CFA franc was revalued against the French franc to counteract most 
of this later devaluation. ${ }^{44}$ These parities remained unchanged until January 1994 and the CFA franc was not again revalued against the French franc; it merely shadowed successive devaluations of the French franc. ${ }^{45}$

On 1 January 1960 the French franc was redenominated. One hundred "old" francs became one "new" franc. Thus from this point onwards (until 1994), one CFA franc $=0.02$ French franc. This radically changed on 12 January 1994 when there was a sharp devaluation of the CFA franc, ostensibly to promote exports from the CFA zone. One CFA franc then became 0.01 French francs. This devaluation was unilaterally announced by Paris with no consultation whatsoever with African leaders. ${ }^{46}$ According to one report, 'Lors de la réunion destinée à informer les dirigeants africains de cette dévaluation, feu le président Bongo du Gabon et d'autres participants ont dit que les émissaires français n'avaient pas demandé leur avis aux chefs d'Etat réunis à Dakar et que tout ce qu'ils avaient à faire était de signer ce qui avait été décidé par Paris avec le soutien du Fonds monétaire international' ${ }^{47}$ The decision was in line with the "doctrine of Abidjan" (also called the "Balladur doctrine") announced in 1993 and which aligned French aid policies to neoliberal principles. ${ }^{48}$

The devaluation created serious (albeit temporary) problems in Franco-African relations. ${ }^{49}$ The step also greatly aggravated economic instability in the CFA countries ${ }^{50}$ and led to the CFA being in the short term undervalued by $23 \% .{ }^{51}$ That the African leaders were not even informed about the devaluation of their own currencies, spoke volumes. ${ }^{52}$ As Agbohou notes, 'The status of African member countries was clear: they were subjected to the monetary whims of the colonizer and thus sovereignty and independence were severely restricted'. ${ }^{53}$ Meanwhile, the purchasing power of the population, particularly the lower classes, was reduced, thus intensifying poverty: prices increased by up to $30 \% .^{54}$

A second major overhaul of the CFA regime also occurred in 1994 when the CFA monetary unions were transformed into economic unions. Treaties were signed establishing the Union Economique et Monétaire Ouest Africaine (UEMOA) and the Communauté Economique et Monétaire de l'Afrique Centrale (CEMAC). UEMOA established an administrative board, consisting of two directors per member state and 
mandated the creation of "National Credit Committees." The establishment of CEMAC also entailed the creation of a similar thirteen member administrative board. ${ }^{55}$

The adoption of the euro by France in 1999 left the monetary agreement of the CFA zone largely unaffected. ${ }^{56}$ When joining the euro area, Paris assured Brussels that changes in the exchange rate of the CFA, or the inclusion of new members, would be conveyed in advance. Additionally, with the EU Council decision of 23 November 1998, any agreements that comprised the CFA arrangements did not imply any obligation for the European Central Bank to support the peg. Consequently, modeled on the Maastricht Treaty, which provided the basis for the European Monetary Union (EMU), 'as if orthodox measures deemed appropriate for the Eurozone were universally applicable, 57 on 1 January 1999, the euro replaced the franc and one hundred CFA francs were now valued at 0.152449 euro (or put another way, 1 euro $=655.957 \mathrm{CFA}$ francs).

Overall, the changes in both 1960 and 1999 were purely adjustments in the currency in use in France; the relative value of the CFA franc against either the French franc or the euro was only changed twice: once in 1948 and then in 1994. In summary, the parity of the CFA franc may be depicted as:

\section{CFA parity ${ }^{58}$}

\begin{tabular}{|l|l|l|}
\hline Creation of the CFA & December 26, 1945 & 1 FCFA $=1.70 \mathrm{FF}$ \\
\hline Devaluation of French franc & October 17, 1948 & 1 FCFA $=2.00 \mathrm{FF}$ \\
\hline Introduction of new French Franc & January 1, 1960 & 1 FCFA $=0.02 \mathrm{FF}$ \\
\hline Devaluation of CFA & January 12,1994 & 1 FCFA $=0.01 \mathrm{FF}$ \\
\hline Securing the CFA to euro & January 1, 1999 & 655.957 FCFA $=1$ euro \\
\hline
\end{tabular}

The point of all of the above is that Paris was the decision maker every step of the way and the CFA member countries in Africa had minimal influence or, as Nkrumah put it, 'A state in the grip of neocolonialism is not master of its own destiny'. ${ }^{59}$ Notably, in December 2016, when CEMAC leaders met to discuss devaluing the currency (a proposal subsequently rejected), 'The summit was held in the presence of IMF Managing Director Christine Lagarde and French finance minister Michel Sapin who were there to give suggestions on the way forward' ${ }^{60}$ Lagarde herself, of course, is French, being exminister of Paris' Ministère de l'économie et des finances. 


\section{The ties that bind}

Intrinsic to the CFA arrangement have been the following obligations to African members of the zone. Firstly, CFA members are required to deposit a minimum of $65 \%$ of their international reserves into an Operations Account (compte d'opérations), located in Paris at the French Treasury (this ratio was modified for UEMOA in September 2005, when it became 50 percent). Secondly, members are required to provide exchange cover for a minimum of $20 \%$ of their sight liabilities i.e. the total deposits which are repayable on demand, not including savings account liabilities or the deposits of any other bank. Finally, members are obliged to place a cap on credit extended to each CFA member country, equivalent to 20 per cent of that country's public revenue in the previous financial year. ${ }^{61}$ Since 2001, this imperative has changed and CFA countries requiring financing must go to the financial market and issue bonds.

The Operations Account is one of the most controversial aspects of the CFA. By stipulating the deposit of such a considerable percentage of CFA members' foreign reserves into a French-directed (and operated) account located in Paris, member states have effectively handed control over their monetary policy to France. The central banks of the CFA zone do not themselves take on the fixed portion of their currencies with the euro; instead, it is the French Treasury (i.e. the State budget, not the Banque de France), which has the power. In exchange for convertibility, the foreign exchange reserves of the CFA members are consolidated. ${ }^{62}$ CEMAC and UEMOA centralize their foreign exchange reserves with their own central banks, which are then obligated to deposit 50\% with the French Treasury into the operations account in Paris. The external value of the CFA is thus entrusted with the former colonial power, in the former colonial capital. The net result is that control over the money supply, monetary and financial regulations and, ultimately, budgetary and economic policies, are in the hands of the former coloniser.

Regarding the common account, no African country is able to say what part of the capital belongs to it. French policy disallows the disclosure of information regarding the investment of this capital by the French Treasury. CFA members are thus unaware where these funds are invested. ${ }^{63}$ Only France has the privilege to access this information and it is evident that the French Treasury profits from these currencies, investing the foreign 
reserves of the CFA states in its own name on the Paris Bourse. At the 55th independence celebrations in Chad in August 2015, President Idriss Déby asked publicly:

Pourquoi cette monnaie n'est pas convertible? Pourquoi tous les échanges passent par la Banque de France? Qu'est-ce que nous gagnons en mettant nos ressources dans des comptes d'opérations? Quel est le taux d'intérêt que nous gagnons? ${ }^{64}$

Thus the head of state of a CFA member, fifty-five years after the French apparently granted independence, publicly admitted that he did not know the interest earned by capital from his own country and deposited in Paris. ${ }^{65}$

A careful examination of the current interest rate paid out by the French Treasury on CFA deposits offers a sharper clarification. In 2014, \$20 billion of African money was held in trust by the French government in the Operations Account. This capital earned 0.75 percent interest (which at the time of writing remains the current interest rate). Yet in that same year, interest rates in France varied from a high of $2.38 \%$ (in January) to a low of $0.92 \%$ (in December). At no point in 2014 did French interest rates pay out as low as the Operations Account did. The following year, as Mar Bassin N'diaye (2016) noted, 'En 2015, la BCEAO et la BEAC ont été contraintes de confier au Trésor français 50\% de leurs réserves, 6700 milliards de FCFA, et n'ont reçu que 45 milliards en intérêts' ${ }^{66}$

Thus the centralization of the currencies of the CFA zone and the lodging of a sizeable portion of their foreign reserves in France helps subsidize the French national budget and hence, French public debt i.e. 'an attractive contribution to the liquid assets of France'. ${ }^{67}$ To what level, no-one knows, due to the secrecy about the account. ${ }^{68}$ It is unclear where the funds are invested, whether there is any profitable return on the investments, and where that profit goes (if there is any). It is alleged however that the reserves made up at least part of the French contribution to the loans given to failing Eurozone countries during the financial crash in $2008 .{ }^{69}$

Furthermore, while the French Treasury disburses the capital generated by interest rates back to the central banks in the CFA zones, 'this interest is included in the amount of French development aid funds given to African states'. ${ }^{70}$ In short, much of what France purports to provide as "aid," are actually funds originating from the recipients 
themselves, now only dressed up as French largesse. In addition, the bulk of French "aid" comes in the form of loans, which have to be paid back, with interest. France's 2018 ODA budget provided for $\$ 291$ million in bilateral economic and financial aid to be disbursed by the Agence Française de Développement; of this, \$216 million (74\%) were loans. ${ }^{71}$ The Operations Account is then a central element of the CFA zones' underdevelopment, in that resources are being actively used, but used in ways which benefits France, not the dependent states from which the resources are sourced.

To compound matters, CFA member states are unable to make use of this capital as collateral to obtain credit lines, as the exchange reserves are held in the name of the French Treasury. As will be detailed below, French representatives sit on the boards of both CFA central banks and thus a de facto French veto exists with regard to setting interest rates and monetary policy. This is a fundamental policy device for sovereign states, but which cannot be exercised by CFA members: 'the CFA Franc Zones [are] beyond the features of a regular currency union'. ${ }^{72}$ Members are thus dependent on Paris to administer and control their own ostensible currency and lack a classic — and basicdefinition of state sovereignty. ${ }^{73}$

Throughout its different expressions, the significant structural underpinnings of the CFA remain neocolonial. Indeed, the CFA is intrinsic to Françafrique, a reality that reflects the fact that the French ruling elites never equated decolonization with retreat, nor fully accepted the idea of African independence. ${ }^{74}$ As one analyst noted, 'De Gaulle may not have regarded [the] transition to "international sovereignty" (as he preferred to call it) as fundamentally important; real independence in the modern world could be enjoyed only by ensembles organists, and he relied upon enlightened self-interest and the pressure of circumstances to keep most African leaders in step' ${ }^{75}$ Remarkably, this has more or less remained today. Indeed, the CFA zone is a central element of a network of intricate webs of political, military, and financial linkages that have for practical purposes put the CFA zone under French control and entrenched dependency. ${ }^{76}$

Central to this fact is that the unlimited convertibility of the CFA into French francs, guaranteed by the Treasury in Paris under Article VIII, Section 2a of the Bretton Woods Agreement, was dissimilar to the norms and settlements of convertibility which the Bretton Woods agreement rested upon. ${ }^{77}$ By this, it is meant that the CFA francs were 
not exchanged on the open currency market. The net result of this was that France enjoyed effective exclusive rights of access to the CFA zone and their primary commodity markets. This simply perpetuated 'a lop-sided dependence on the export of raw materials, and the import of manufactured goods'. ${ }^{78}$ This structural dependence on one or two commodities can be most easily seen in CEMAC, which is disproportionately reliant on oil for its economic exports.

CEMAC: Relative Economic Size and Importance of Oil Sector, $2015^{79}$

\begin{tabular}{|l|l|l|l|}
\hline & $\begin{array}{l}\text { GDP as \% of } \\
\text { CEMAC's GDP }\end{array}$ & Oil as \% of GDP & $\begin{array}{l}\text { Oil exports as \% of } \\
\text { country's exports }\end{array}$ \\
\hline Cameroon & 38.7 & 4.7 & 38.5 \\
\hline CAR & 2.2 & 0.0 & 0.0 \\
\hline Chad & 14.8 & 20.0 & 78.0 \\
\hline Congo-B & 12.2 & 40.5 & 74.4 \\
\hline Eq. Guinea & 12.8 & 30.0 & 81.4 \\
\hline Gabon & 19.4 & 31.8 & 76.5 \\
\hline
\end{tabular}

Just prior to the slump in oil prices in mid-2014, the oil sector represented 29 percent of CEMAC's GDP; 79 percent of its exports; and 54 percent of regional government revenue. A wider look at the economic structures of the two CFA zones' members shows just how utterly dependent they are on primary commodities for their export income. This is important, given that the CFA currency is fixed at an overvalued rate, which favours the urban areas, which can buy imported goods relatively inexpensively but at the expense of farmers and other commodity producers. ${ }^{80}$ Equally, the high dependence on commodities with the CFA zones increases the prospect of asymmetric shocks and of pro-cyclical fiscal behaviour. ${ }^{81}$

Three main exports, with their share in total exports, $2017^{82}$

\begin{tabular}{|l|l|l|l|}
\hline & Product I & Product II & Product III \\
\hline Benin & Non-crude oil (40.1\%) & Light oils (13.6\%) & Cotton $(9.6 \%)$ \\
\hline Burkina Faso & Gold (65.2\%) & Cotton $(19.8 \%)$ & \\
\hline Cameroon & Fish $(32.6 \%)$ & & \\
\hline
\end{tabular}




\begin{tabular}{|c|c|c|c|}
\hline CAR & Wood $(44.0 \%)$ & Cotton $(20.6 \%)$ & Sawn wood (16.8\%) \\
\hline Chad & Crude oil $(95.2 \%)$ & & \\
\hline Comoros & Cloves $(53.4 \%)$ & Vanilla $(14.5 \%)$ & $\begin{array}{l}\text { Sea vessels for } \\
\text { breaking up }(12.6 \%)\end{array}$ \\
\hline Congo-B & Crude oil $(78.9 \%)$ & $\begin{array}{l}\text { Copper } \quad \text { cathodes } \\
(9.9 \%)\end{array}$ & \\
\hline Côte d'Ivoire & Cocoa $(33.9 \%)$ & Cocoa paste $(7.6 \%)$ & $\begin{array}{l}\text { Cocoa butter, fat and } \\
\text { oil }(5.6 \%)\end{array}$ \\
\hline Eq. Guinea & Crude oil $(68.2 \%)$ & Natural gas $(23.5 \%)$ & \\
\hline Gabon & Crude oil (81.3\%) & Manganese $(8.5 \%)$ & \\
\hline Guinea-B & Cashew nuts $(75.0 \%)$ & Wood $(19.8 \%)$ & \\
\hline Mali & Cotton $(43.0 \%)$ & Gold $(34.2 \%)$ & Sesame seeds $(6.2 \%)$ \\
\hline Niger & Light oils $(32.3 \%)$ & Non-crude oil (19.7\%) & $\begin{array}{l}\text { Sesame seeds } \\
(16.2 \%)\end{array}$ \\
\hline Senegal & Gold (16.8\%) & Fish $(10.3 \%)$ & $\begin{array}{l}\text { Phosphoric acid } \\
(7.3 \%)\end{array}$ \\
\hline Togo & Gold $(24.6 \%)$ & Non-crude oil (18.2\%) & $\begin{array}{l}\text { Electrical energy } \\
(6.2 \%)\end{array}$ \\
\hline
\end{tabular}

French colonialism inserted Paris' African territories into the global system in a dependent position whereby extraction was the dominant mode of production; the CFA arrangement has perpetuated this reality. Commenting upon the UEMOA, the IMF recently stated that 'Growth in the [UEMOA] has been lower and more volatile over the past 25 years than in comparable countries and the structure of the economy has changed little. The majority of the region's population is employed in low-productivity agriculture and the secondary sector is underdeveloped'. ${ }^{83}$ This is surely a comment of the continuing effects of the CFA.

A currency is a tool operated by a state (or group of states) to carry out programmes to further economic goals. As the problems with the euro have demonstrated within the European Union, if a currency hampers the accomplishment of such goals or is perceived to be damaging to the national good, policymakers question the virtue of such arrangements. Regarding the CFA, analysts have long interrogated the CFA fixed exchange rate parity and its effect on member countries' economies. ${ }^{84}$ If policymakers indeed note that the arrangements are deleterious to the nation, they should, in the best interests of their country or countries, contemplate an alternative to this currency and the 
monetary regime therewith associated' ${ }^{85}$ This assumes however that the national good is a priority (or even on the list of priorities). In many of the CFA countries, this cannot by any means be assumed. Rather, for the ruling elites in the CFA zone, the fixed rate has been beneficial for them and is part of the membership dues for Françafrique. Furthermore, French businesses have benefited from the CFA zone whilst the main advantage to Paris is political in that with fourteen African countries within the orbit of France, it can claim to be a global power. The mutual interests between French and local ruling elites in the CFA countries thus come together to promote a high degree of inertia with regard to reconsidering the arrangement. Otherwise, 'Very few economic rationales, if any, could justify such a (misaligned) rate that has hurt and continues to impact negatively the economies of these countries' ${ }^{86}$

The status quo is further solidified by the governance arrangements which have been mentioned previously, but serves to prevent any effective change. At the BEAC, the Board of Directors is made up of thirteen members, with three representing France; the BCEAO board has eighteen members, two of whom are appointed by Paris. ${ }^{87}$ This presence of French interests at the level of one of the key decision-making bodies is critical. The Board of Directors administers the Central Bank and ensures its functioning. In addition to their presence in Board, Paris has a right of veto in that the Board of BEAC constitutes a quorum only if each participating state is represented by at least one director (the BCEAO can only make changes to its statutes if there is an unanimous agreement). Perhaps even more serious, the veto right for France also extends to the appointment of the Governor of BEAC, as Article 50, Paragraph 1 of the Articles of BEAC states that the Governor can only be appointed by the Conference of Heads of State of CEMAC, upon the proposal of the Ministerial Committee of the L'Union Monétaire de l'Afrique Centrale (the organ responsible for monetary policy) and after the unanimous approval of the Administrative Council.

At the BCEAO, the Board of Directors is made up of the Governor of the Central Bank, a member appointed by each of the Governments of the UEMOA member states and a member appointed by the state that guarantees the convertibility of the common currency i.e. France. This arrangement is very similar to the BEAC and Article 82 of the statutes of the BCEAO stresses that any changes in its own statutes and other key 
decisions must be reached with the complete unanimity of the Board of Directors. Though African members are in the majority on the Board of Directors of both currencies, they have no real control in the management of operations without French say-so. As Dominique Kounkou notes, this arrangement confirms classically to "la théorie des traités inégaux' i.e. the theory of unequal treaties which were intrinsic to colonialism. ${ }^{88}$

Ironically, the greatest losers out of the CFA arrangement are those with positive Operations Account balances (i.e. those with the most disciplined fiscal policy) and who trade outside of the CFA zones. Although French monopolization of the CFA market has noticeably diminished in the wake of post-2000 investment by BRICS countries, it is well documented that the ready convertibility of the CFA in conjunction with the fact that the French Treasury has the sole obligation of this convertibility, means French corporations receive an unfair competitive advantage. ${ }^{89}$ The convertibility has also encouraged massive capital flight from the CFA zone, again to the benefit of France, which is the main destination of capital leaving the zone.

Indeed, capital flight from the franc zone has been enormous, having a demonstrable negative effect on poverty reduction. ${ }^{90}$ A detailed study by Ameth Saloum Ndiaye of Université Cheikh Anta Diop de Dakar ${ }^{91}$ has demonstrated quite clearly that between 1970 and 2010, ten of the fourteen CFA countries recorded net capital outflows. ${ }^{92}$ Among these ten, four faced capital flight with an amount surpassing $\$ 10$ billion. At the top of this list was Côte d'Ivoire, with c. $\$ 40$ billion leaving the country. Gabon lost c. \$23 billion, Congo-Brazzaville \$20 billion, and Cameroon c. \$11 billion. All of the six countries in CEMAC experienced capital flight of varying quantities, while only four countries in UEMOA recorded on balance capital inflows (Burkina Faso, Côte d'Ivoire, Guinea-Bissau, and Togo). Capital flight from the franc zone is generated primarily by corporations via trade misinvoicing, corrupt officials in Africa and by wellpositioned individuals banking in France, all facilitated by the convertibility of the CFA, guaranteed by Paris. The net result is that between 1970 and 2010, UEMOA saw $\$ 19.4$ billion leave the zone whilst CEMAC witnessed $\$ 67.5$ billion exiting overseas. ${ }^{93}$ Of note, 'In Cameroon, Côte d'Ivoire, Gabon....and Togo, investing flight capital in domestic economies over the same period would have increased the annual rate of poverty reduction by more than 10 percentage points'. ${ }^{94}$ 


\section{The CFA Helps Deepens Underdevelopment}

It is apparent that the CFA acts as mechanism that helps promotes inertia and underdevelopment for its member states. This is deeply problematic given that there is a desperate need to promote structural change, 'defined as an increase in the share of industry or services in the economy, or as the diversification and sophistication of exports...or as the shift of workers from sectors with low labour productivity to those with high labour productivity' in Africa. ${ }^{95}$ The question of structural transformation is at the heart of the development project on the continent, as only returns on value chains will enable African economies to exchange goods and services that are sufficiently diversified and that may allow the possibility of increasing value on exports. Here a number of issues arise.

Firstly, the economies of the CFA zone experience major problems regarding the price competitiveness of their exports, due to the fixed exchange rate with the euro which, as has been mentioned, makes the CFA an overvalued currency. ${ }^{96}$ Senegal, for example, recorded an overvaluation of the real exchange rate estimated at between $10 \%$ and $35 \%$ in 2013-2014. ${ }^{97}$ The strength of the CFA then acts as an effective tax on exports and a subsidy on imports. In a study of 12 countries, It has been found that on average CFA countries' currencies were overvalued by 31 percent in 1993 (just prior to the devaluation), with Cameroon's real exchange rate being overvalued by a colossal 78 percent. ${ }^{98}$ A later, post-devaluation study, found that the average overvaluation for the CFA zone was $25 \%{ }^{99}$

The burden on exports then makes it extremely difficult to nurture any infant industries that may contribute to diversification, setting aside the fact that foreign reserves that may be deployed to do this are kept in the Operations Account in Paris. It is well-known that African economies exhibit very low levels of diversification and that by all measures there has been limited diversification of African economies. ${ }^{100}$ The CFA countries are particularly problematic in this respect. The table below looks at the Concentration Index and the Diversification Index of the CFA zone in comparison with other regions. The Concentration Index (also named the Herfindahl-Hirschmann Index), is a measure of the degree of product concentration. The methodology obtains data values 
between 0 and 1, with an index value closer to 1 indicating a country's trade is highly concentrated on a few products. The Diversification Index measures the absolute deviation of the trade structure of a country from the global structure. A value closer to 1 indicates greater divergence from the world pattern.

Concentration and Diversification indices ${ }^{101}$

\begin{tabular}{|l|l|l|l|l|l|l|l|l|l|l|}
\hline Region & \multicolumn{3}{l}{$\mathbf{1 9 9 5}$} & \multicolumn{2}{l}{$\mathbf{2 0 0 0}$} & \multicolumn{2}{l}{$\mathbf{2 0 0 5}$} & $\mathbf{2 0 1 0}$ & $\mathbf{2 0 1 5}$ & \\
\hline & CI & DI & CI & DI & CI & DI & CI & DI & CI & DI \\
\hline CEMAC & 0.5 & 0.8 & 0.6 & 0.8 & 0.8 & 0.8 & 0.7 & 0.8 & 0.6 & 0.8 \\
\hline UEMOA & 0.2 & 0.8 & 0.2 & 0.8 & 0.2 & 0.7 & 0.2 & 0.7 & 0.3 & 0.7 \\
\hline COMESA & 0.3 & 0.7 & 0.4 & 0.7 & 0.4 & 0.6 & 0.4 & 0.6 & 0.2 & 0.5 \\
\hline EAC & 0.3 & 0.7 & 0.2 & 0.7 & 0.2 & 0.7 & 0.1 & 0.7 & 0.1 & 0.6 \\
\hline SADC & 0.1 & 0.5 & 0.2 & 0.5 & 0.2 & 0.6 & 0.3 & 0.5 & 0.2 & 0.5 \\
\hline
\end{tabular}

The above date demonstrates that both CFA zones are significantly less diversified than other important regional blocs in Africa, whilst the Concentration Index for both is poor, with CEMAC particularly acute, when compared with other regional blocs. Furthermore, as one study has found, the growth rate of industrial exports in the CFA zones is below that of other African countries. ${ }^{102}$

In this regard, it is important to consider the critique by Bruno Tinel, economist at the Sorbonne, who notes that while the GDP of the CFA zones represent less than $10 \%$ of France's total GDP, operating the currency and guaranteeing its convertibility remains a manageable prospect for Paris. Yet within this system is an in-built rationale within CFA to ensure the underdevelopment of the African economies, lest their economic size become too unwieldy for France to oversee:

Si les économies des deux sous-régions CFA venaient à se développer et à grossir trop vite, la France serait moins en mesure d'assumer ce paternalisme monétaire à leur égard. En des termes moins polémiques: ce système est faisable tant que les économies de la zone CFA demeurent de petite taille au regard de celle de l'économie française. ${ }^{103}$ 
It is not necessary to enter into the realms of conspiracy theories to see the logic behind such an assertion.

\section{The CFA as a Currency Union and Economic Commonsense}

An intriguing phenomena regarding the CFA zone is that as currency areas, they do not actually make economic sense, given the structures of their membership countries. When discussing currency unions in general, two advantages are routinely cited. ${ }^{104}$ The first is the reduction in transaction costs, in that the expenses involved in exchanging currencies are averted as a unitary currency is employed for all intraregional commerce. Supplementary costs such as may be incurred on futures markets to hedge against risks in exchange rates, as well as information costs, are also avoided. Obviously, the lessening of transaction costs is limited to dealings within a currency union. ${ }^{105}$ The relative gains of reduced transactions costs is consequently significant if and when intraregional trade is substantial as a percentage of total trade. Weak intraregional trade negates the advantage. ${ }^{106}$

Secondly, exchange rate risks accompanying future capital flows in foreign currencies is avoided. Due to fluctuations in the exchange rate, it is likely that future receipts denominated in foreign currencies decline in value in the local currency. Having one nominated coinage for a currency union removes this exchange rate risk for intraregional trade as expenditures and earnings from intraregional trade will be held in the currency of the zone. ${ }^{107}$ Again, low intraregional trade makes this ostensible advantage of a currency union less relevant. In short, the literature on optimal currency areas (OCAs) states that an OCA is classified as a region typified by factor mobility, economic interdependence, sectoral diversification and flexibility in wages and prices. ${ }^{108}$ If one looks at the level of intraregional trade within the two CFA zones, it is apparent that neither fulfil OCA conditions. ${ }^{109}$ CEMAC has the lowest proportion of intra-regional trade in Africa, at just 2.1\% in 2014 while UEMOA's intra-regional trade has stagnated. In contrast, the East African Community (EAC) and the Southern African Development Community (SADC) fare significantly better; in 2014, SADC had the highest proportion of intra-regional trade at $19.3 \%$ of its total trade, followed by the EAC at $18.4 \%$. 
Intra-regional trade in Africa's regional economic communities as a percentage of total trade ${ }^{110}$

\begin{tabular}{|l|l|l|l|}
\hline & $\mathbf{2 0 0 0}$ & $\mathbf{2 0 1 0}$ & $\mathbf{2 0 1 4}$ \\
\hline CEMAC & 1.19 & 2.74 & 2.08 \\
\hline COMESA & 4.82 & 7.36 & 11.00 \\
\hline EAC & 17.73 & 18.65 & 18.37 \\
\hline ECOWAS & 8.91 & 8.27 & 8.92 \\
\hline SADC & 11.73 & 18.18 & 19.34 \\
\hline UEMOA & 15.24 & 15.24 & 15.30 \\
\hline
\end{tabular}

As BNP Paribas notes:

The CFA franc zone has not fulfilled all its objectives by a long shot, particularly in terms of regional integration. Trade within the WAEMU barely exceeds $10 \%$ of total trade flows, and what is more, this percentage has been relatively stable over the long term. Intra-zone trade within the CEMAC is even smaller. ${ }^{111}$

This directly contradicts the official view of the Banque de France which incorrectly claims that "monetary union has strengthened regional solidarity. The existence of a common currency, combined with free capital flows, is a factor that promotes the development of trade within both the WAEMU and the CEMAC'. ${ }^{112}$

Given that the two zones demonstrably do not fulfill the notional conditions that may give rise to an optimal usage of a currency union, it would be apposite to then discuss some of the disadvantages of currency unions. Unfortunately, the CFA zone fulfills all of these shortcomings. Firstly, currency unions remove the possibility of member states utilizing exchange rate adjustments as a policy mechanism within the zone. Members cannot alter the nominal exchange rate, which may result in problems vis-a-vis balance of payments. In normal economies (non-currency unions), the real exchange rate is influenced by vagaries in wages and prices, as well as labour productivity. This is not possible in a currency union such as CFA. Secondly, in currency unions, monetary policy is centralized and state-level monetary policy is not possible. It 
has been demonstrated that if countries are confronted with identical shocks, they require different policy responses to these shocks due to the differences in their economic positions. ${ }^{113}$ This is not possible within the CFA zone and, in any case, monetary policy is de facto controlled by the former colonial power, with a different key rate for the BEAC (3.5\%) and BCEAO (2.5\%). Thirdly, monetary integration necessitates both the harmonization of inflation rates and the real cost increases within members' states. Increases in remunerations relative to labour productivity in a member country will stimulate joblessness and will likely trigger factor shifts to higher productivity economies within the bloc. The fiscal and monetary discipline imposed on the CFA zone has meant that member countries have been constrained in their spending on social provisions. Not for nothing does Agbohou note that 'monetary bondage leads to subjugation and underdevelopment'. ${ }^{114}$

Equally, large-scale disparities in income between member states of a union is problematic. A look at the per capita income of the member states within the two CFA zones reveals that this is indeed the case:

\section{Per capita income, 2014 (in \$) 115}

\begin{tabular}{|l|l|l|l|}
\hline UEMOA country & Per capita income & CEMAC country & Per capita income \\
\hline Benin & 900 & Cameroon & 1350 \\
\hline Burkina Faso & 680 & CAR & 320 \\
\hline Côte d'Ivoire & 1450 & Chad & 980 \\
\hline Guinea-Bissau & 590 & Congo-B & 2720 \\
\hline Mali & 790 & Equatorial Guinea & 16028 \\
\hline Niger & 420 & Gabon & 10410 \\
\hline Senegal & 1020 & & \\
\hline Togo & 550 & & \\
\hline
\end{tabular}

Monetary integration in a situation as depicted above, encourages regional imbalances and intensifies inequalities within zones. This will then likely encourage migration within such unions to economies where per capita income is higher and employment 
opportunities exist, which in turn may kindle societal tensions. The history of Côte d'Ivoire is a clear example of this trend. ${ }^{116}$

The compensations of monetary unions such as found in the CFA zone are significant only when intraregional trade is relatively large. This is not the case in either CFA zones. ${ }^{117}$ Even the European Union admits that 'Taking the literature on the optimal currency area ("OCA") as a reference, the CFA franc zone countries would hardly qualify for an OCA given their low product diversification'. ${ }^{118}$ Weak intra-zonal trade is a recurrent feature of both zones (CEMAC being worse in this regard than UEMOA) and the practical extraversion of the CFA zones' economies makes it almost pointless to share the same currency. ${ }^{119}$ But share it they do.

\section{Conclusion}

If dependency is a condition that acts to limit the developmental possibilities of subordinate economies and 'a situation in which the economy of a certain group of countries is conditioned by the development and expansion of another economy' (Dos Santos, 1971: 226), then the CFA is a classic example. It is undoubtable that the CFA encourages capital flight and corruption, whilst preventing effective economic diversification and perpetuating commodity dependence:

$[T]$ he CFA franc is an obstacle to the development of Africa countries. The operating mechanisms of the franc zone and the monetary policies imposed on those countries are largely responsible for the failure of the CFA franc to be an instrument of development. An illustration of this failure is reflected in the economic and social realities of those countries, almost all of which are ranked as least developed countries (LDCs) or as heavily indebted poor countries (HIPCs). ${ }^{120}$

Consequently, the CFA zone countries have been effectively locked into a "comparative advantage" of supplying cheap commodities. That this advantage accrues to Paris and its allies across Africa is quite evident:

$[U] n$ taux de change qui est surévalué et qui, par conséquent, handicape les exportations des pays africains, mais, par contre, donne un avantage aux classes 
possédantes locales parce qu'elles peuvent bénéficier d'une importation facile, non contrôlée, des biens de consommation de semi-luxe, disons, qui ne devraient pas être prioritaires dans les importations de ces pays. C'est, par conséquent, un instrument qui renforce ce que l'on appelle le néocolonialisme dans le langage general. ${ }^{121}$

This overvaluation has continued. If 1999 is taken as the base year, the nominal appreciation rate relative to the US dollar stood at $24.2 \%$ in 2011, after hitting a high of $27.3 \%$ in 2008. After the devaluation in 1994, the bulk of CFA member countries experienced a gradual appreciation, to the point of attaining an overvaluation, from 2004 onwards. ${ }^{122}$

However, mainstream analysis of the technical aspects of the CFA miss the point: 'Disputes about the optimal exchange rate can be misleading. The true value of the CFA franc is not economic. It is political. For the member states of the franc zone have no national monetary policy of their own. The making of monetary policy for these countries remains with France'. ${ }^{123}$ It is the symbolic manifestation of a hangover from colonialism that is at the heart of most critiques of the CFA: 'La grande violence symbolique du maintien très visible d'un rapport colonial doit être soulignée. Les symboles, ça compte. ${ }^{124}$

Indeed, scrutiny of the CFA zone has been largely dominated by orthodox economists who, while able to provide technical analyses of its functioning, cannot account for its longevity when based on "rational" economics. This is because the CFA is, first and foremost, a political instrument: as one analysis by economists admits:

The CFA countries constitute a puzzle from the standpoint of OCA analysis. They have successfully maintained a currency union despite their failure to meet a number of important OCA criteria. This can be explained by several drawbacks of the OCA analysis, the stronger coming from its "problem of inconclusiveness" and its omission of political considerations. ${ }^{125}$

The 'omission of political considerations' can be explained in that it raises troubling questions about French policy in Africa and the complicity of the elites of Françafrique. 
Indeed, institutions and norms associated with the CFA reproduce a hierarchical relationship between France and its former colonies. From the African side i.e. the normal people, 'The benefits from economic integration within each of the two monetary unions of the CFA franc zone, and even more so between them, remain remarkably low'. ${ }^{126}$ The structures of the Paris-village $d u$ continent noir, of which the CFA is the most obvious, continue. While the military interventions by France may be the most dramatic, the more mundane economic constraints are far more damaging and amount to 'a voluntary surrender of sovereignty'. ${ }^{127}$

In short, the CFA arrangements continue to exhibit structural expressions of underdevelopment and dependency, in that the CFA serves as an instrument to suck capital and economic surplus out of former (largely French) colonial territories in Africa. In an evaluation of the CFA, Célestin Monga wryly noted:

Looking at the economic challenges facing African policymakers today-at a time when 1 billion people still live below a very low income poverty rate (arbitrarily) set at US\$1.25 a day-it is hard not to wonder about their decisionmaking process on crucial issues such as the choice of an exchange rate, and their increasing willingness to join or create monetary unions which they hope will help their economies escape from perpetual misery.

...Perhaps a hundred years from now when future economic historians use the tools of behavioral economics to analyze the policy decisions made by the African policymakers - especially their either passive, uninformed, or stubborn willingness to join, remain in, or create monetary unions that clearly hampered their already difficult quest for prosperity - the rationality underlying the choices made will seem clearer than they are today. ${ }^{128}$

It is of course important in this respect to acknowledge African agency in the CFA story. Francophone leaders on the continent are well-known for their attachment to Paris, manipulating relations for the sake of their own regimes' survival in policies that fit JeanFrançois Bayart's concept of extraversion. ${ }^{129}$ Equally, the "cover" provided to these selfsame elites by the CFA arrangements is critical. Such leaders can be sure that Paris will always be there to protect their mistakes, which at the same time serves as a 
disincentive to make structural reforms. It is no wonder that the CFA countries are lagging in terms of governance indicator, as the 2018 Ibrahim Index of African Governances attests. The current African average governance score is 49.9/100. Fully nine out of the fourteen CFA countries (all of those within CEMAC) are either below the continental average or barely pass this (already low) marker. Given the intense political role that Paris exercises in these countries, this is surely an indictment of French policy in much of Africa.

Governance Indicators (out of 100) ${ }^{130}$

\begin{tabular}{|l|l|l|l|}
\hline UEMOA country & & CEMAC country & \\
\hline Benin & 58.7 & Cameroon & 46.2 \\
\hline Burkina Faso & 57.1 & CAR & 29.5 \\
\hline Côte d'Ivoire & 54.5 & Chad & 35.4 \\
\hline Guinea-Bissau & 40.2 & Congo-B & 39.8 \\
\hline Mali & 50.1 & Equatorial Guinea & 30.9 \\
\hline Niger & 51.2 & Gabon & 42.4 \\
\hline Senegal & 63.3 & & \\
\hline Togo & 50.5 & & \\
\hline
\end{tabular}

Only when the leaders of these countries become an obvious liability to French interests will they be discarded. But as long as they play the game they are generally safe.

Yet it is not enough to blame Françafrique entirely on Paris: postcolonial Francophone Africa has seen an active participation by its governing elites in the processes that have continued the continent's dependent position within the global system - what Kako Nubukpo has referred to as a move from imposed extraversion to chosen extraversion. ${ }^{131}$ Indeed, while 'Dependency could not be more evident than in the continued use of a metropolitan currency', this situation has been preserved by the consent of the ruling elites of le village franco-africain. ${ }^{132}$

Given the insecurity of most African regimes, focusing on survival is key and the Françafrique regime, of which the CFA is a central element, is an excellent example of how African elites are responsible in certain ways for the perpetuation of dependency 
relations. ${ }^{133}$ This was neatly encapsulated by the former president of Gabon, Omar Bongo, who noted that 'Le Gabon sans la France, c'est une voiture sans chauffeur, la France sans le Gabon, c'est une voiture sans carburant'. ${ }^{134}$ It is this reality of dependency that Golan alluded to her in original analysis of the mystery of how France gets away with it.

Yet, at some point, the CFA arrangements will have to be transformed. This is not only because of the deleterious economic conditions that are fostered within the zones, and all the other technical arguments made against the currency, but also because it is a residue of a colonial past that is now under increasing scrutiny and critiqued by many within the zone themselves. In 1956, Kwame Nkrumah wrote that 'The best way of learning to be an independent sovereign state is to be an independent sovereign state'. ${ }^{135}$ Sixty years later, the CFA countries may be moving towards this radical option.

${ }^{1}$ BBC News, 2019.

${ }^{2}$ See e.g. "Francophone Africa's CFA", The Economist, 2019; "The African Currency at the Center of a European Dispute", New York Times, 2019; "La zone Franc et le Franc CFA méritent un sérieux dépoussiérage", Le Monde, 2019; "Does French-backed CFA franc keep some African countries poor?", East African, 2019.

${ }^{3}$ Alby, CFA Franc: A New Stress Test, p. 2.

${ }^{4}$ Konkobo, "African Protests Over the CFA."

${ }^{5}$ Deutsche Welle, "The CFA Franc in West Africa."

${ }^{6}$ Golan, ““'A Certain Mystery.”

${ }^{7}$ Note that two non-Francophone countries have voluntarily joined the CFA zone: Equatorial Guinea (a former Spanish colony) adopted the CFA franc in 1985, replacing the Equatorial Guinean currency at a rate of 1 CFA franc to 4 bipkwele. Guinea-Bissau (a former Portuguese colony) joined the CFA zone in 1997 at a rate of 1 CFA franc to 65 pesos.

${ }^{8}$ Amin, Neo-colonialism in West Africa.

${ }^{9}$ Glaser and Smith, Ces messieurs Afrique.

${ }^{10}$ Vershave, Francafrique.

${ }^{11}$ Heilbrunner, "Oil and Water?" François-Xavier Verschave playfully noted that Francafrique could also be "France à fric" (fric being slang for "cash").

${ }^{12}$ Siradağ, "Understanding French Foreign and Security Policy Towards Africa."

${ }^{13}$ Mbaye, "The CFA Franc at the Crossroads," 65

${ }^{14}$ Howard, Power and Glory.

15 "In return, through this "monetary paternalism", France would gain prestige, an illustration to the world stage of the maintenance of the empire, a domain in which its influence would remain intact, at a time when competition from emerging countries 
(China, India, Russia, Brazil) is stronger than ever", Le Monde, "La zone Franc et le Franc CFA", 2019.

16 This is particularly so given the rise of China and other "emerging powers" on the continent, which have undermined France's pre-eminence in economic matters in a number of Francophone countries on the continent.

${ }^{17}$ Nkrumah, Neo-colonialism.

18 Martin, "The Franc Zone"; Martin, "Continuity and Change in Franco-African Relations."

${ }^{19}$ See Langan, Neo-colonialism and the Poverty of "Development" in Africa.

${ }^{20}$ Rodney, How Europe Underdeveloped Africa.

${ }^{21}$ See Nubukpo, "Management of the CFA Franc in West Africa."

22 Vallin, "France as the Gendarme of Africa," 80.

${ }^{23}$ In addition to the official CFA countries, since 1979 Comoros has been in a monetary cooperation agreement with Paris. There is a system of fixed parity between the Comorian franc and the euro (previously the French franc). This is guaranteed by the Comorian central banks operations account at the French Treasury. Sixty-five percent of the foreign exchange reserves of Comoros are held in euros in this account. When the ministers of finance of the CFA zone and France meet biannually, the Comorian finance minister also attends and the arrangement between France and the Comoros is fundamentally the same as that between France and the CFA Zone.

${ }^{24}$ Note that there have been changes in the membership of the zone. In 1960, Guinea left and began issuing Guinean francs, followed in 1962 by Mali. In 1973 Mauritania left, the CFA franc with the ouguiya, followed in 1974 when Madagascar ditched the zone when the Banque Centrale de Madagascar began issuing banknotes. In 1975 and 1976 Réunion and Mayotte left the zone and adopted the French franc (subsequently the euro). As noted above, Equatorial Guinea and Guinea-Bissau joined the zone in 1985 and 1997 respectively. In 1984, Mali rejoined the CFA franc zone.

${ }^{25}$ CEEAC consists of Cameroon, Central African Republic, Congo, Gabon, Equatorial Guinea and Chad. The CFA franc in this zone is issued by the Banque des Etats de l'Afrique Centrale (BEAC).

${ }^{26}$ UEMOA consists of Benin, Burkina Faso, Côte d'Ivoire, Guinea Bissau, Mali, Niger, Senegal and Togo. The CFA franc in this zone is issued by the Banque Centrale des États de l'Afrique de l'Ouest (BCEAO). Note that UEMOA is known in English as the West African Economic and Monetary Union (WAEMU).

27 See Chafer and Keese Francophone Africa at Fifty; Andereggen, France's Relationship with Sub-Saharan Africa; Martin, "Continuity and Change in FrancoAfrican Relations"; Manning, Francophone Sub-Saharan Africa 1880-1995; Chafer, "French African Policy in Historical Perspective"; Chafer, "Hollande and Africa Policy"; Gregory, "The French Military in Africa"; Charbonneau, "Dreams of Empire"; Charbonneau, France and the New Imperialism; Cumming, "Burying the Hatchet?"; Sun and Zoubir, "Sentry Box in the Backyard."

28 See Dembélé and Cardoso, Wither the Franc Zone in Africa?; Nubukpo, Tinel, Belinga and Dembélé, Sortir l"'Afrique de la servitude monétaire.

${ }^{29}$ Suret-Canale, French Colonialism in Tropical Africa.

${ }^{30}$ Ginio, French Colonialism Unmasked; Jennings, Free French Africa in World War II.

${ }^{31}$ Aldrich, Greater France. 
32 Lombard and Carayannis, "Making Sense of CAR", 10. See also Dumont and Mottin, Stranglehold on Africa.

${ }^{33}$ Charbonneau, France and the New Imperialism, 282.

${ }^{34}$ The French colonial empire on the continent was divided into two federations: Afrique occidentale français (AOF) and Afrique-Occidentale français (AEF).

${ }^{35}$ Van de Walle, "The Decline of the Franc Zone", 388.

36 Vallin, "France as the Gendarme of Africa," 79.

37 Tchatchouang, "The CFA Franc Zone".

${ }^{38}$ Wauthier, "France and Africa".

39 Engberg, "The Operations Account".

40 Yansane, "African Unity", 54.

${ }^{41}$ White, Black Africa and De Gaulle.

42 Des' Adom, "Beyond the CFA Franc," 75.

${ }^{43}$ Prior to this, one local colonial franc was worth one French franc.

44 Stasavage, The Politics of a Common Currency.

45 This successfully happened inter alia (number of French francs to the dollar): 27 April, 1949, 2.72; 20 September 1949, 3.5; 11 August 1957, 4.2; 27 December 1958, 4.93; 10 August 1969, 5.5.

${ }^{46}$ Devarajan and Rodrik, Do the Benefits of Fixed Exchange Rates Outweigh their Costs? Remarkably, Jean-Claude Tchatchouang's chapter on the CFA in the Oxford Handbook of Africa and Economics (Tchatchouang, 2015) claims that the countries of the FCA zone as a whole elected to devalue the CFA franc. This is not true.

47 "During the meeting to inform African leaders of this devaluation, the late President Bongo of Gabon and other participants said that the French emissaries had not asked their opinion of the heads of state gathered in Dakar and that all that they had to do was to sign up to what had been decided by Paris with the support of the International Monetary Fund" - Le Monde Afrique, "Regain de rébellion africaine contre «la servitude monétaire» du franc CFA".

${ }^{48}$ See Jacquemot, "Fifty Years of French Cooperation with Sub-Saharan Africa".

${ }^{49}$ Körner, "The Franc Zone of West and Central Africa".

50 Azam, "Poverty and Growth in the WAEMU after the 1994 Devaluation".

${ }^{51}$ Rodrik, The Real Exchange and Economic Growth.

${ }^{52}$ See Elbadawi and Majd, "Adjustment and Economic Performance Under a Fixed Exchange Rate".

${ }^{53}$ Agbohou, "The CFA Franc", 41.

${ }^{54}$ Alby, CFA Franc: A New Stress Test, p. 7.

${ }^{55}$ Devarajan and Hinkle, "The CFA Franc Parity Change".

${ }^{56}$ Fouda and Stasavage, "The CFA Franc Zone After EMU".

57 Tamba, "Euro Area Sovereign Debt Crisis", 189.

58 BCEAO, "Histoire du Franc CFA".

${ }^{59}$ Nkrumah, Neo-colonialism, $\mathrm{x}$.

${ }^{60}$ Boh, "CEMAC Heads of State Reject CFA Franc Devaluation".

${ }^{61}$ Canac and Garcia-Contreras, "Colonial Hangover", 55.

${ }^{62}$ Giorgioni, "The CFA Franc Zone".

63 Dufrénot, "Monetary Autonomy in the West African Countries", 68. 
64 "Why is this currency not convertible? Why do all exchanges go through the Bank of France? What do we gain by putting our resources into trading accounts. What is the interest rate we earn?" - quoted by Survie, "Déby et le CFA".

${ }^{65}$ Why Déby and his peers have not done anything about this, would be the subject of another article.

66 "In 2015, the BCEAO and BEAC were forced to give the French Treasury 50\% of their reserves, 6700 billion CFA, and received only 45 billion in interest" - N'diaye, "Franc CFA".

${ }^{67}$ Harshe, "French Neo-Colonialism in Sub-Saharan Africa", 168.

${ }^{68}$ Neuwirth, "African Monetary Union Stirs Criticism of France".

${ }^{69}$ Allison, "The Gilded Cage".

${ }^{70}$ Gegout, Why Europe Intervenes in Africa, 142.

${ }^{71}$ Donortracker.

${ }^{72}$ Martínez-Zarzoso, The Euro and the CFA Franc, 5.

${ }^{73}$ Krasner, "Sovereignty".

${ }^{74}$ Chafer, The End of Empire in French West Africa.

${ }^{75}$ Hargreaves, "Book review", 439.

${ }^{76}$ Bongyu, "The Economic and Monetary Community of Central Africa".

${ }^{77}$ Canac and Garcia-Contreras, "Colonial Hangover", 61.

${ }^{78}$ Harris, "The Political Economy of Africa", 12.

${ }^{79}$ UNCTADSTAT, "Merchandise".

${ }^{80}$ During the second half of the 1980s, CFA countries experienced a prolonged decline of their terms of trade and a nominal appreciation of their currencies (due to the French francs' rise against the US dollar). This resulted in an overvalued exchange rate.

${ }^{81}$ Martínez-Zarzoso, The Euro and the CFA Franc, 5.

${ }^{82}$ COMTRADE WITS Online Database.

${ }^{83} \mathrm{IMF}$, "West African Economic and Monetary Union Common Policies of Member Countries".

${ }^{84}$ See Agbohou, Le Franc CFA et l'Euro contre l'Afrique; 99; Stasavage, The Politics of a Common Currency.

${ }^{85}$ Des' Adom, "Beyond the CFA Franc", 72.

${ }^{86}$ Ibid.

87 Agbohou, "The CFA Franc", 43.

${ }^{88}$ Quoted in Ouvertures "Le franc CFA".

${ }^{89}$ Bayart, "Africa in the World", 220.

${ }^{90}$ See Nkurunziza, Capital Flight and Poverty Reduction in Africa, 2014.

${ }^{91}$ N'diaye, "Franc CFA".

92 Namely, Burkina Faso, Cameroon, Central African Republic, Chad, Congo, Côte d'Ivoire, Equatorial Guinea, Gabon, Guinea-Bissau, and Togo.

${ }^{93}$ N'diaye, "Franc CFA".

${ }^{94}$ Nkurunziza, Capital Flight and Poverty Reduction in Africa, p. 36.

${ }^{95}$ Sindzingre, "The Ambivalent Impact of Commodities", 26.

${ }^{96}$ Coulibaly, "Competitiveness and Growth Within the CFA Franc Zone".

97 Deguenonvo, Real Exchange Rate Misalignment in Senegal.

${ }^{98}$ Devarajan, "Real Exchange Rate Misalignment in the CFA Zone". 
${ }^{99}$ Etta-Nkwelle, Jeong, and Fanara, "Misalignment of the Real Exchange Rate".

${ }^{100}$ Ben Hammouda, Karingi, Njuguna and Jallab, "Africa's (Mis)-fortunes in Global Trade".

${ }^{101}$ UNCTADSTAT, "Merchandise".

102 Cottet, Madariaga, and Jégou, La diversification des exportations en zone franc.

103 "If the economies of the two CFA subregions were to develop and to grow too fast, France would be less able to assume this monetary paternalism towards them. In less polemical terms: this system is feasible as long as the savings of the CFA zone remain small compared to that of the French economy" - Tinel, Le fonctionnement des comptes d'opérations, 2016, p. 7.

${ }^{104}$ Alesina and Barro, "Currency Unions".

${ }^{105}$ Mundell, "A Theory of Optimum Currency Areas".

${ }^{106}$ Carrère, "African Regional Agreements".

${ }^{107}$ Ishiyama, "The Theory of Optimum Currency Areas", 362.

108 Masson and Taylor, "Optimal Currency Areas".

${ }^{109}$ See Coulibaly and Gnimassoun, "Optimality of a Monetary Union".

${ }^{110}$ African Development Bank, African Economic Outlook, 2016, 83.

111 Alby, CFA Franc: A New Stress Test, p. 3.

112 Banque de France, 'The Franc Zone', p. 10.

113 Mélitz, "Brussels on a Single Money".

${ }^{114}$ Agbohou, "The CFA Franc", p. 54.

115 World Bank, "Poverty and Equity Data".

116 See Araoye, Côte d'Ivoire.

117 Couharde, Coulibaly, Guerreiro, and Mignon, Revisiting the Theory of Optimum Currency Areas.

${ }^{118}$ Hallett, The Role of the Euro in Sub-Saharan Africa, 10.

${ }^{119}$ Ndao, "What Makes the CFA Franc Zone a Special Form of Monetary Integration?", 499.

${ }^{120}$ Dembélé, "Preface", xi-xii.

121 "An exchange rate that is overstated and therefore handicaps African countries exports, but gives an advantage to the local landowning classes because they can benefit from easy, uncontrolled importation of semi-luxury consumption goods, say, which should not be given priority in imports from these countries. It is, therefore, an instrument that reinforces what is called neocolonialism in general language" - quoted by Radio France International, "Samir Amin".

122 Gnansounou and Verdier-Chouchane, Gnansounou, Misalignment of the Real Effective Exchange Rate, 21.

123 Yates, "France and Africa", 105.

124 "The big symbolic violence of a very visible maintenance of a colonial relationship must be underlined. The symbols count", Tinel, Le fonctionnement des comptes d'opérations, p. 7.

125 Couharde, Coulibaly, Guerreiro, and Mignon, Revisiting the Theory of Optimum Currency Areas.

${ }^{126}$ Hallett, The Role of the Euro in Sub-Saharan Africa and in the CFA Franc Zone, 12.

${ }^{127}$ Martin, "Continuity and Change in Franco-African Relations", 201. 
${ }^{128}$ Monga, "African Monetary Unions," 131.

${ }^{129}$ Bayart, "“'Africa in the World".

${ }^{130}$ Ibrahim Index of African Governance, 2018.

${ }^{131}$ Nubukpo, "Management of the CFA Franc in West Africa."

132 O'Brien, "The Show of State in a Neo-colonial Twilight."

133 Bovcon, "Françafrique and Regime Theory."

134 'Gabon without France is like a car without a driver. France without Gabon is like a car without fuel', Fall, 'Omar Bongo et la France'.

${ }^{135}$ Nkrumah, Axioms of Kwame Nkrumah, 67.

\section{References}

African Development Bank. African Economic Outlook, 2016: Sustainable Cities and Structural Transformation. Abidjan: African Development Bank, 2016.

Agbohou Nicolas. Le Franc CFA et l'Euro contre l'Afrique. Paris: Editions Solidarité Mondiale, 1999.

Agbohou, Nicolas. "The CFA Franc: A Vector of Monetary Nazism" in Dembélé and Cardoso, 2015: 40-60.

Alby, Stéphane. CFA Franc: A New Stress Test Paris: BNP Paribas, 2018.

Aldrich, Robert. Greater France: A History of French Overseas Expansion. Basingstoke: Palgrave, 1996.

Alesina, Alberto and Barro, Robert. "Currency Unions", Quarterly Journal of Economics, (117) 2, 2002: 409-436.

Allison, Simon. "The Gilded Cage: Who Does the CFA Franc Really Benefit? 2015, https://www.howwemadeitinafrica.com/the-gilded-cage-who-does-the-cfa-francreally-benefit/

Amin, Samir. Neo-colonialism in West Africa. Harmondsworth: Penguin Books, 1973.

Andereggen, Anton. France's Relationship with Sub-Saharan Africa. Westport, CT: Praeger, 1994.

Araoye, Lasisi. Côte d'Ivoire: The Conundrum of a Still Wretched of the Earth. Trenton, NJ: Africa World Press, 2012.

Armah, Ayi Kwei. "Africa and the Francophone Dream", West Africa (3582), 1986: 28.

Azam, Jean-Paul. "Poverty and Growth in the WAEMU after the 1994 Devaluation", United Nations University World Institute for Development Economics Research, Research Paper, 2004.

Banque de France, 'The Franc Zone'. Paris: Communication Directorate, 2010.

Bayart, Jean-François. "Africa in the World: A History of Extraversion", African Affairs, (99), 395, 2000: 217-267.

BBC News 'France Summons Italian Envoy Over Africa Remarks', 22 January, 2019, https:/www.bbc.co.uk/news/world-europe-46955006

BCEAO. "Histoire du Franc CFA", 2017. http://www.bceao.int/Histoire-du-FrancCFA,55.html

Ben Hammouda, Hakim, Karingi, Stephen, Njuguna, Anjelica and Jallab, Mustapha. "Africa's (Mis)-fortunes in Global Trade and the Continent's Diversification Regimes", Journal of World Investment and Trade (7) 4, 2006: 587-616. 
Boh, Elvis. "CEMAC Heads of State Reject CFA Franc Devaluation", 12 December, 2016, http://www.africanews.com/2016/12/24/cemac-heads-of-state-reject-cfafranc-devaluation//

Bongyu, Moye Godwin. "The Economic and Monetary Community of Central Africa (CEMAC) and the Decline of Sovereignty", Journal of Asian and African Studies (44) 4, 2009: 389-406.

Bovcon, Maja. "Françafrique and Regime Theory", European Journal of International Relations, (19), 1, 2011: 5-26.

Canac, Pierre and Garcia-Contreras, Rogelio. "Colonial Hangover: The Case of the CFA", Journal of Asian and African Studies (46) 1, 2011: 54-68.

Carrère, Céline. "African Regional Agreements: Impact on Trade With or Without Currency Unions", Journal of African Economies (13) 2, 2004: 199-239.

Chafer, Tony. "French African Policy in Historical Perspective", Journal of Contemporary African Studies, (19) 2, 2001: 165-182.

Chafer, Tony. The End of Empire in French West Africa: France's Successful Decolonization? New York, NY: Berg, 2002.

Chafer, Tony. "Hollande and Africa Policy", Modern and Contemporary France, (22) 4, 2014: 513-531.

Chafer, Tony and Keese, Alexander Francophone Africa at Fifty Manchester: Manchester University Press, 2013.

Charbonneau, Bruno. "Dreams of Empire: France, Europe, and the New Interventionism in Africa", Modern and Contemporary France, 16 (3), 2008: 279-295

Charbonneau, Bruno. France and the New Imperialism: Security Policy in Sub-Saharan Africa. Aldershot: Ashgate, 2008.

Cottet, Christophe, Madariaga, Nicole and Jégou, Nicolas. La diversification des exportations en zone franc : degré, sophistication et dynamique. Paris: MacroDev de l"Agence française de développement, 2012.

Couharde, Cécile, Coulibaly, Issiaka, Guerreiro, David and Mignon, Valérie. Revisiting the Theory of Optimum Currency Areas: Is the CFA Franc Zone Sustainable? CEPII, WP No 2012-13 Paris: Centre d'Études Prospectives et d'Informations Internationales, 2013.

Coulibaly, Issiaka. "Competitiveness and Growth Within the CFA Franc Zone: Does the Switch to the Euro Matter?" International Economics (139) 1, 2014: 1-18.

Coulibaly, Issiaka and Gnimassoun, Blaise. "Optimality of a Monetary Union: New Evidence from Exchange Rate Misalignments in West Africa", Economic Modelling, 32, 2013: 463-482.

Crowder, Michael and O'Brien, Donal Cruise. "French West Africa 1945-1960" in Crowder, Michael and Ajayi, J. F. A. (eds.). The Cambridge History of Africa, Volume 8. Cambridge: Cambridge University Press, 1984: 664-699.

Cumming, Gordon. "Burying the Hatchet? Britain and France in the Democratic Republic of Congo", Journal of Modern African Studies, (49) 4, 2011: 547-73.

Deguenonvo, Cédric. Real Exchange Rate Misalignment in Senegal: Effect on Growth. MPRA Paper No. 84338, Munich: Munich Personal RePEc Archive, 2017.

Dembélé, Demba Moussa. "Preface" in Dembélé and Cardoso, 2015: xi-xii. 
Dembélé, Demba Moussa and Cardoso, Carlos (eds.). Wither the Franc Zone in Africa? Dakar: Council for the Development of Social Science Research in Africa, 2015.

Des' Adom, Assandé. "Beyond the CFA Franc: An Empirical Analysis of the Choice of an Exchange Rate Regime in the UEMOA”, Economic Issues (17) 2, 2012: 71-93.

Deutsche Welle. "The CFA Franc in West Africa: Time for a Change?", 22 June, 2018, https://www.dw.com/en/the-cfa-franc-in-west-africa-time-for-a-change/a44348656

Devarajan, Shantayanan. "Real Exchange Rate Misalignment in the CFA Zone", Journal of African Economies (6) 1, 1997: 35-53.

Devarajan, Shantayanan and Hinkle, Lawrence. "The CFA Franc Parity Change: An Opportunity to Restore Growth and Reduce Poverty", Africa Spectrum (29) 2, 1994: 131-151.

Devarajan, Shantayanan and Rodrik, Dani. Do the Benefits of Fixed Exchange Rates Outweigh their Costs? The Franc Zone in Africa. Working Paper No. 3727. Cambridge, MA: National Bureau of Economic Research, 1991.

Donortracker. "France Donor Profile", 2018, https://donortracker.org/country/france

Dos Santos, Theotonio. "The Structure of Dependence" in Fann, K.T. and Hodges, Donald (eds.) Readings in U.S. Imperialism Boston, MA: Porter Sargent, 1971.

Dufrénot, Gilles "Monetary Autonomy in the West African Countries: What do the Policy Rules Tell Us?”, Journal of International Development, (23), 63-81, 2011.

Dumont, René and Mottin, Marie-France. Stranglehold on Africa. London: Andre Deutsch Limited, 1983.

East African. "Does French-backed CFA franc keep some African countries poor?", East African, 25 January, 2019.

The Economist "Francophone Africa's CFA", 27 January, 2019.

Elbadawi, Ibrahim and Majd, Nader. "Adjustment and Economic Performance Under a Fixed Exchange Rate: A Comparative Analysis of the CFA Zone", World Development, (24) 5, 1996: 939-951.

Engberg, Holger. "The Operations Account System in French-Speaking Africa”, Journal of Modem African Studies, (11) 4, 1973: 537-545.

Etta-Nkwelle, Maru, Jeong, Jin-Gil and Fanara, Philip. "Misalignment of the Real Exchange Rate in the African Financial Community (CFA Zone) and its Policy Implications", Applied Financial Economics, (20) 15, 2010: 1205-1215.

Fall, Jean-Karim. 'Omar Bongo et la France'. Radio France International, June 8, 2006, http://www1.rfi.fr/actufr/articles/113/article_81262.asp

Fouda, Seraphin and Stasavage, David. "The CFA Franc Zone After EMU: Status Quo, Reform, or Dissolution?" World Economy (23) 2, 2000: 221-233.

Gegout, Catherine. Why Europe Intervenes in Africa: Security Prestige and the Legacy of Colonialism. London: Hurst Publishers, 2017.

Ginio, Ruth. French Colonialism Unmasked: the Vichy years in French West Africa. Lincoln, NE: University of Nebraska Press, 2006.

Giorgioni, Gianluigi. "The CFA Franc Zone: A Political Re-evaluation Twenty Years After the Advent of the Euro", Journal of Contemporary African Studies (advanced print), 2018. 
Glaser, Antoine and Smith, Stephen. Ces messieurs Afrique 1: Le Paris-village du continent noir. Paris: Calmann-Lévy, 1992.

Gnansounou, Sosthène and Verdier-Chouchane, Audrey. Misalignment of the Real Effective Exchange Rate: When Should the Franc CFA be Devalued Again? Tunis: African Development Bank, 2012.

Golan, Tamar. "A Certain Mystery: How Can France Do Everything That It Does in Africa - And Get Away With It?”, African Affairs, 80 (318), 1981: 3-11.

Gregory, Shaun. "The French Military in Africa: Past and Present", African Affairs (99) 396, 2000: 435-448.

Gulde, Anne Marie. "Overview" in Gulde, Anne Marie and Tsangarides, Charalambos (eds.). The CFA Franc Zone: Common Currency, Uncommon Challenges. Washington DC: International Monetary Fund, 2008.

Hallett, Martin. The Role of the Euro in Sub-Saharan Africa and in the CFA Franc Zone. Brussels: European Commission, 2008.

Hargreaves, John. "Book review of La Politique africaine du Général de Gaulle", African Affairs (81) 324, 1982: 438-440.

Harris, David. "The Political Economy of Africa: Underdevelopment or Revolution" in Harris, D. (ed.). The Political Economy of Africa. New York, NY: Schenkman, 1975: 1-48.

Harshe, Rajen. "French Neo-Colonialism in Sub-Saharan Africa", India Quarterly: A Journal of International Affairs (36) 2, 1980: 159-178.

Heilbrunner, John. "Oil and Water? Elite Politicians and Corruption in France", Comparative Politics (37) 3, 2005: 277-296.

Howard, R.T. Power and Glory: France's Secret Wars with Britain and America 19452016. London: Biteback Publishing, 2016.

Ibrahim Index of African Governance, 2018, http://iiag.online/

IMF. "West African Economic and Monetary Union Common Policies of Member Countries-Staff Report; Press Release; and Statement by the Executive Director", Washington DC: International Monetary Fund, 2015.

Ishiyama, Yoshihide. "The Theory of Optimum Currency Areas: A Survey", IMF Staff Papers (22) 2, 1975: 344-83.

Jacquemot, Pierre. "Fifty Years of French Cooperation with Sub-Saharan Africa: An Overview (Part 1)", Afrique contemporaine, (238), 2011: 43-57.

Jennings, E. Free French Africa in World War II: The African Renaissance. Cambridge: Cambridge University Press, 2015.

Konkobo, Lamine. "African Protests Over the CFA "Colonial Currency"”, BBC News, August 30, 2017, https://www.bbc.co.uk/news/world-africa-41094094

Körner, Heiko. "The Franc Zone of West and Central Africa: A Satellite System of European Monetary Union”, Intereconomics (37) 4, 2002: 198-203.

Koutonin, Mawuna Remarque. "14 African Countries Forced by France to Pay Colonial Tax For the Benefits of Slavery and Colonization", 28 January, 2014, http://www.siliconafrica.com/france-colonial-tax/

Krasner, Stephen. "Sovereignty", Foreign Policy, (122), 2001: 20-29.

Langan, Mark. Neo-colonialism and the Poverty of "Development" in Africa. Basingstoke: Palgrave, 2018. 
Le Monde. "La zone Franc et le Franc CFA méritent un sérieux dépoussiérage", January 26, 2019.

Le Monde Afrique. "Regain de rébellion africaine contre «la servitude monétaire» du franc CFA", $30 \quad$ September, https://www.lemonde.fr/afrique/article/2016/09/30/debut-de-rebellion-africainecontre-la-servitude-monetaire-du-franc-cfa 5006237 3212.html

Le Vine, Victor. Politics in Francophone Africa. Boulder, CO: Lynne Rienner, 2004.

Lombard, Louise and Carayannis, Tatiana "Making Sense of CAR: An Introduction" in Carayannis, Tatiana and Lombard, Louise (eds.). Making Sense of the Central African Republic. London: Zed Books, 2015: 1-16.

Manning, Patrick. Francophone Sub-Saharan Africa 1880-1995. Cambridge University Press, 1998.

Martin, Guy. "The Franc Zone: Underdevelopment and Dependency in Francophone Africa", Third World Quarterly, (8) 1, 1986: 205-235.

Martin, Guy. "Continuity and Change in Franco-African Relations", Journal of Modern African Studies (33) 1, 1995: 1-20.

Martínez-Zarzoso, Inmaculada. The Euro and the CFA Franc: Evidence of Sectoral Trade Effects. Göttingen: Center for European Governance and Economic Development Research, 2017.

Masson, Paul and Taylor Mark. "Optimal Currency Areas: A Fresh Look at the Traditional Criteria" in Siklos, Pierre (ed.) Varieties of Monetary Reforms: Lessons and Experiences on the Road to Monetary Union. Boston, MA: Kluwer Academic Press, 1994.

Mbaye, Sanou (2015) "The CFA Franc at the Crossroads: Reforming or Dismantling?" in Dembélé and Cardoso, 61-70.

Médard, Jean-François. "France and Sub-Saharan Africa: A Privileged Relationship" in Engel, Ulf and Olsen, Gorm Rye (eds.) Africa and the North: Between Globalization and Marginalization. London: Routledge, 2005: 38-54.

Mélitz, Jacques. "Brussels on a Single Money", Open Economies Review, (2), 1991: 323336.

Monga, Célestin. "African Monetary Unions: An Obituary" in Monga, Célestin and Lin, Justin Yifu. (eds.) The Oxford Handbook of Africa and Economics: Volume 2: Policies and Practices. Oxford: Oxford University Press, 2015.

Mundell, Robert. "A Theory of Optimum Currency Areas", American Economic Review, (51), 4, 1991: 657-665.

Ndao, Souleymane. "What Makes the CFA Franc Zone a Special Form of Monetary Integration?" Economic Alternatives, (4), 2016: 491-499.

N'diaye, Mar Bassin. "Franc CFA: Comment l"Afrique finance gratuitement la France", Le360afrique, 10 August, 2016, http://afrique.le360.ma/cote-divoire-senegalguinee-mali-gabon-autres-pays/economie/2016/07/30/4320-franc-cfa-commentlafrique-finance-gratuitement-la

N'diaye, Ameth Saloum Ndiaye. "Capital Flight and its Determinants in the Franc Zone", African Journal of Economic Policy, 16(1), 2009: 65-104. 
N'diaye, Ameth Saloum Ndiaye. "Is Capital Flight from the Franc Zone Countries Decisive in Explaining their Economic Growth Performance?" Revue Economique et Monetaire (20), 2016: 7-34.

Neuwirth, Robert. "African Monetary Union Stirs Criticism of France”, Bloomberg, 24 April, 2014, https://www.bloomberg.com/news/articles/2014-04-17/africanmonetary-union-stirs-criticism-of-france.

The New York Times. "The African Currency at the Center of a European Dispute", New York Times, 22 January, 2019.

Nkrumah, Kwame. Neo-colonialism: The Last Stage of Imperialism. New York, NY: International Publishers, 1965.

Nkrumah, Kwame. Axioms of Kwame Nkrumah. London: Panaf Books, 1967.

Nkurunziza, Janvier. Capital Flight and Poverty Reduction in Africa 2014. Amherst, MA: Political Economy Research Institute, 2014.

Nubukpo Kako. "Management of the CFA Franc in West Africa: From an Imposed Extroversion to Chosen Extroversion?" in Padayachee, Vishnu (ed.) The Political Economy of Africa. London: Routledge, 2010: 357-368.

Nubukpo, Kako, Tinel, Bruno, Belinga, Martial Ze, and Dembélé, Demba Moussa. Sortir l"Afrique de la servitude monétaire: A qui profite le franc CFA? Paris: La Dispute, 2016.

O'Brien, Donal Cruise. "The Show of State in a Neo-colonial Twilight: Francophone Africa" in James Manor (ed.) Rethinking Third World Politics. London: Longman, 1991.

Ouvertures. "Le franc CFA toujours contrôlé par Paris", February 2, 2009, http://www.ouvertures.net/le-franc-cfa-toujours-controle-par-paris/

Radio France. "Samir Amin: "Le colonialisme, c"est l"abolition formelle de la souveraineté nationale"،, interview with Florence Morice, 13 March, 2017, transcript available at: www.rfi.fr/emission/20170313-samir-amin-franceanticolonial-tiers-monde-ua-independances-colonisation-imperiali

Rodrik, Dani. The Real Exchange and Economic Growth. Washington DC: Brookings Papers on Economic Activities, 2008.

Rodney, Walter. How Europe Underdeveloped Africa. London: Bogle-L"Ouverture Publications, 1972.

Sichone, Owen. "France in Africa: A Pan-Africanist Perspective" in Dubey, A. (ed.) India and Francophone Africa Under Globalization New Delhi: African Association of African Studies, 2009.

Sindzingre, Alice. "The Ambivalent Impact of Commodities: Structural Change or Status Quo in Sub-Saharan Africa?", South African Journal of International Affairs (20) 1, 2013: 23-55.

Siradağ, Abdurrahim. "Understanding French Foreign and Security Policy Towards Africa: Pragmatism or Altruism”, Afro Eurasian Studies Journal (3) 1, 2014: 100122.

Stasavage, David. The Politics of a Common Currency: The CFA Franc Zone Since 1945. Aldershot: Ashgate Publishers, 2003. 
Sun, Degan and Zoubir, Yahia. "Sentry Box in the Backyard: Analysis of French Military Bases in Africa", Journal of Middle Eastern and Islamic Studies (in Asia), (5) 3, 2011: 82-104.

Suret-Canale, Jean. French Colonialism in Tropical Africa, 1900-1945. London: Hurst Publishers, 1971.

Survie. "Déby et le CFA, les vérités du faussaire", 1 September, 2015, http://survie.org/billets-d-afrique/2015/249-septembre-2015/article/deby-et-le-cfales-verites-du-4996

Tamba, Isaac. "Euro Area Sovereign Debt Crisis: What Economic Policy Consequences and Implications for the Franc Zone African Countries?" International Journal of Economics and Finance (4) 8, 2012: 186-195.

Tchatchouang, Jean-Claude. "The CFA Franc Zone: A Biography" in Monga, Célestin and Lin, Justin Yifu (eds.) The Oxford Handbook of Africa and Economics: Volume 2: Policies and Practices. Oxford: Oxford University Press, 2015.

Tinel, Bruno. Le fonctionnement des comptes d'opérations et leur rôle dans les relations entre la France et les pays africains Paris: Centre d'Economie de la Sorbonne, 2016.

UNCTADSTAT. "Merchandise: Product Concentration and Diversification Indices by Economy, Annual, 1995-2015”, 2017, http://unctadstat.unctad.org/wds/TableViewer/tableView.aspx?ReportId=120

Vallin, Victor-Manuel. "France as the Gendarme of Africa, 1960-2014", Political Science Quarterly, (130) 1, 2015: 79-101.

Van de Walle, Nicholas. "The Decline of the Franc Zone: Monetary Politics in Francophone Africa", African Affairs (90) 360, 1991: 383-405.

Vershave, François-Xavier. Francafrique: la plus long scandale de la republique. Paris: Stock, 2003.

Wauthier, Claude. "France and Africa: "Long Live Neo-Colonialism"”, Issue: A Journal of Opinion (2) 1, 1972: 23-26.

White, Dorothy. Black Africa and De Gaulle: From the French Empire to Independence. University Park, PA: Pennsylvania University Press, 1979.

World Bank. "Poverty and Equity Data", 2016, http://povertydata.worldbank.org/poverty/country/

Yansane, A.Y. "African Unity: Obstacles and Advances", Africa Today, (24) 3, 1977: 4359.

Yates, Douglas. "France and Africa" in Dawn Nagar and Charles Mutasa (eds.) Africa and the World: Bilateral and Multilateral International Diplomacy Berlin: Springer, 2018. 